\title{
Effect of Frying on Nutrients Content and Fatty Acid Composition of Muscles of Selected Freezing Seafoods
}

\author{
Anna Czech ${ }^{1, *}$, Eugeniusz R Grela², Katarzyna Ognik ${ }^{3}$ \\ ${ }^{1}$ Department of Biochemistry and Toxicology, University of Life Sciences in Lublin, Akademicka 13, 20-934 Lublin, Poland \\ ${ }^{2}$ Institute of Animal Nutrition and Bromatology, University of Life Sciences in Lublin \\ *Corresponding author: annaczech@poczta.fm
}

Received November 18, 2014; Revised December 10, 2014; Accepted December 30, 2014

\begin{abstract}
Shellfish are low in fat content. They are especially low in saturated fatty acids (SFAs), but are rich in omega-3 FA. Because heat processing and oil additive could change the FA profile, we determined the effect frying of frozen seafood on the content of nutrients, FA composition and some lipid indices. Analyses were conducted on tissues of clams, Japanese squid, white shrimp and octopus. Frozen octopuses were characterized by a low content of monoenic (MUFAs - 11.8\%) and a high polyunsaturated (PUFAs - 54.3\%) and FAs of the n-3 family compared to shrimps, squids and clams. The seafood's were fried in a sunflower oil $\left(170 \pm 5^{\circ} \mathrm{C}, 6-8 \mathrm{~min}\right)$. Frying decreased SFAs and n-3 FAs and increased PUFAs and n-6 FAs contents, which corresponds to a significant increase in n-6/n-3 ratio, which we attribute to the use of sunflower oil for frying, since it is a rich source of these acids. A decrease was noted in atherogenic and thrombogenic FA indices, and a significant increase in $\mathrm{h} / \mathrm{H}$ ratio, beneficial from the nutritional point of view.
\end{abstract}

Keywords: seafood, muscles, nutrients, fatty acids, frying

Cite This Article: Anna Czech, Eugeniusz R Grela, and Katarzyna Ognik, "Effect of Frying on Nutrients Content and Fatty Acid Composition of Muscles of Selected Freezing Seafoods." Journal of Food and Nutrition Research, vol. 3, no. 1 (2015): 9-14. doi: 10.12691/jfnr-3-1-2.

\section{Introduction}

Shellfish are low in fat, especially low in saturated fatty acids (SFA), contain omega-3 fatty acids, and are excellent protein sources. The omega-3 fatty acids found in seafood are derived from phytoplankton, the small aquatic plant cells that are sources of food for many aquatic organisms [1]. They are found throughout the food chain, including fish and shellfish that are used in a human diet. The content of total fat and omega- 3 fatty acids found in different species of fish and shellfish can vary depending on a number of factors including the diet of each species, the season and location of the catch, the age and physiological status of the individual organism, and reproductive cycles. In most cases the content of omega-3 fatty acids is related to the total fat content of the species $[2,3]$.

Total lipid content was reported to range from $0.7 \%$ in sea scallops to $3.1 \%$ in clams and from $1.2 \%$ in Dungeness crab to $1.3 \%$ in pink shrimp [4]. Five fatty acids (16:0, 16:1, 18:1, 20:5n-3, and 22:6n-3) represented from $60 \%$ to $84 \%$ of the total fatty acid content (FA). Palmitic acid ranged from $13 \%$ to $32 \%$ of the total fatty acids. Long-chain n-3 polyunsaturated fatty acids (n-3 PUFAs) were predominant (37.6\% to $54.3 \%)$. Sea scallops contained more than 50\%; n-6 PUFAs, ranging from $1.5 \%$ to $6.5 \%$ [4]. The American Heart Association recommends eating a variety of fish and shellfish at least twice a week because they are excellent sources of protein, good sources of omega-3 fatty acids, and are low in saturated fatty acids [5].

To preserve their high quality seafoods should be stored at a temperature of ca. $-30^{\circ} \mathrm{C}$. However, freezing causes deterioration of sensory and functional properties of meat, mainly as a result of diminished solubility of proteins and water absorbability [6]. Stability of frozen food products depends on their quality, the method used to prevent oxidation and water evaporation, as well as on temperature of storage. In countries with no direct access to catching sites of seafoods (e.g. Poland), these products are available on the market only in frozen or marinated form.

Therefore the aim of this study was to examine what extent thermal processing (frying) frozen Mediterranean diet (ie. bivalves - mussels, squid Japanese white shrimp and octopus) will influence on the content of basic nutrients and fatty acid profile.

\section{Material and Methods}

The experimental material were selected species of food products of the Mediterranean diet, i.e. clams (Mytilus edulis), Japanese squids (Todarodes pacificus), white shrimps (Penaeus setiferus) and octopuses (Octopus vulgaris). Since Poland is a country without access to fresh seafoods from own catches, they must be imported. 
In this study, the analyzed invertebrates were purchased as frozen products in retail stores. The purchased products came from Thailand. Six packs for of each $1000 \mathrm{~g}$ of each species (clams, Japanese squid, white shrimp and octopus) were immediately thawed at a temperature of $20-22^{\circ} \mathrm{C}$ for 2 hours, and then inedible parts were removed. Muscle in squid, shrimps and octopus, and the whole soft part in clams were salted $(10 \% \mathrm{NaCl})$, and after 10 minutes the excess of salt was removed. The products were coated with wheat flour (type 650) and deep-fried on a stainless steel pan. The products were fried using a sunflower oil (total SFAs: $10 \mathrm{~g}$, total monoenoic fatty acids (MUFAs): 18.9 g, total PUFAs: 71.1 g, PUFA n-3 0,63 g and PUFA n-6 $70.5 \mathrm{~g} 100^{-1} \mathrm{~g} \mathrm{FA}$ ) heated to a temperature of $170 \pm 5^{\circ} \mathrm{C}$, for 6-8 minutes. The oil was discarded after each fried batch. The frozen and fried seafood fruits were homogenized and mixed in order to achieve uniform initial material. Afterwards, appropriate weighted portions of the samples were prepared for assay. In total, 72 samples of the invertebrates were analyzed (4 species $x 2$ forms x 3 purchase sites x 3 replications) [7].

Samples of experimental material, sunflower oil used for frying and wheat flour used for coating were measured for their content of basic nutrients and fatty acid composition.

\subsection{Chemical Analyses}

The food products were analyzed for dry matter (DM), crude protein (CP - 976.06), and crude ash (968.08) using the AOAC [8] procedures. Total fat of shrimp, squid, clams and octopus for fatty acid analysis was extracted with a chloroform/methanol mixture according to Folch et al. [9].

Fatty acids were determined using the gaseous chromatography method on a Varian CP-3800 chromatograph. The chromatograph operating conditions for fatty acid separation were: capillary column CP WAX 52CB DF $0.25 \mathrm{~mm}$ of $60 \mathrm{~m}$ length, gas carrier - helium, flow rate $-1.4 \mathrm{~mL} / \mathrm{min}$, column temperature $120^{\circ} \mathrm{C}$ gradually increasing by $2^{\circ} \mathrm{C} / \mathrm{min}$, determination time $127 \mathrm{~min}$, injector temperature $-160^{\circ} \mathrm{C}$, detector temperature $-160^{\circ} \mathrm{C}$, other gases - hydrogen and oxygen.

The fatty acid content in the products (seafood, flour and oil) was calculated according to information contained in [10]. Lipid quality indices, i.e. atherogenicity index (AI) and thrombogenicity index (TI) were calculated according to the [11] equations:

$\mathrm{AI}=[(4 \times \mathrm{C} 14: 0)+\mathrm{C} 16: 0] /[\mathrm{n}-6$

PUFA $+n-3$

PUFA+MUFA];

$\mathrm{TI}=[\mathrm{C} 14: 0+\mathrm{C} 16: 0+\mathrm{C} 18: 0] /[(0.5 \times \mathrm{MUFA})+(0.5 \times \mathrm{n}-$

6 PUFA $)+(3 \times n-3$ PUFA $)+n-3 / n-6$ PUFA].

Hypocholesterolemic/Hypercholesterolemic ratio $(\mathrm{h} / \mathrm{H})$ was obtained according to [12].

$\mathrm{h} / \mathrm{H}=(\mathrm{C} 18: 1+\mathrm{C} 18: 2+\mathrm{C} 18: 3+\mathrm{C} 20: 3+\mathrm{C} 20: 4+\mathrm{C} 20: 5+\mathrm{C} 22:$ 4+C22:5+C22:6)/(C14:0+C16:0).

\subsection{Statistical Analysis}

Results achieved were analyzed statistically with the ANOVA test. The LSD value was calculated in the Statistica 5.0 PL 97 software, and results were presented as mean values and standard deviation.

\section{Results and Discussion}

Components of the Mediterranean diet, including seafoods, constitute a significant source of protein, minerals, vitamins and unsaturated fatty acids, especially polyunsaturated fatty acids of the n-3 family.

\subsection{Content of Basic Nutrients and Fatty Acids in the Muscle Of Seafoods}

The nutritive value of protein from tissues of invertebrates is similar to that of egg and milk proteins, and higher than that of meat from mammals [13]. This is determined by the morphology of muscle tissue. Owing to its specific structure, protein of the invertebrates is better digestible, and their meat requires shorter heat treatment. A significantly higher protein content in the analyzed invertebrates, was noted in octopuses compared to the other products analyzed - shrimps, squids, and clams (Table 1). Research by Ozogul et al. [14] demonstrates, however, a higher concentration of protein in tissues of squids (Loligo vulgaris) compared to tissues of octopuses of the species Eledone moschat, and Octopus vulgaris. The protein content is subject to fluctuations during the maturation cycle and diet of marine animals, as evidenced by the reported differences.

Table 1. Content of dry matter (DM), crude protein (CP) crude ash (CA) and crude fat (CF) (\% wet mass) in some products of the Mediterranean diet

\begin{tabular}{|c|c|c|c|c|c|}
\hline Item & & Shrimp & Squid & Clams & Octopus \\
\hline \multirow[t]{2}{*}{ DM } & Freezing & $10.04^{b} \pm 1.76$ & $12.31^{b} \pm 1.06$ & $13.42^{b} \pm 1.68$ & $20.45^{\mathrm{a} \pm 2.06}$ \\
\hline & Frying & $59.14^{b} \pm 3.55$ & $67.08^{\mathrm{a}} \pm 4.88$ & $54.87^{\mathrm{C}} \pm 5.62$ & $59.16^{b} \pm 5.12$ \\
\hline \multirow[t]{2}{*}{$\mathrm{CP}$} & Freezing & $8.66^{\mathrm{b}} \pm 0.99$ & $9.98^{\mathrm{b}} \pm 1.61$ & $10.98^{\mathrm{b}} \pm 1.74$ & $18.30^{\mathrm{a}} \pm 1.81$ \\
\hline & Frying & $16.56^{b} \pm 2.11$ & $18.41^{\mathrm{ab}} \pm 2.29$ & $18.95^{\mathrm{ab}} \pm 1.04$ & $21.15^{\mathrm{a}} \pm 2.37$ \\
\hline \multirow[t]{2}{*}{ CA } & Freezing & $0.89^{b} \pm 0.13$ & $1.20^{\mathrm{ab}} \pm 0.32$ & $1.53^{\mathrm{a}} \pm 0.24$ & $0.90^{b} \pm 0.11$ \\
\hline & Frying & $2.05^{\mathrm{b}} \pm 0.39$ & $2.50^{\mathrm{ab}} \pm 0.37$ & $2.98^{\mathrm{a}} \pm 0.41$ & $2.09^{b} \pm 0.35$ \\
\hline \multirow[t]{2}{*}{$\mathrm{CF}$} & Freezing & $0.40^{b} \pm 0.03$ & $1.24^{\mathrm{a}} \pm 0.17$ & $0.72^{\mathrm{ab}} \pm 0.12$ & $0.93^{\mathrm{a}} \pm 0.18$ \\
\hline & Frying & $39.78^{b} \pm 3.58$ & $45.47^{\mathrm{a}} \pm 4.22$ & $32.42^{\mathrm{b}} \pm 2.81$ & $35.13^{b} \pm 3.69$ \\
\hline \multicolumn{2}{|c|}{ DM x treatment } & 0.006 & 0.005 & 0.004 & 0.008 \\
\hline \multicolumn{2}{|c|}{ TP $\mathrm{x}$ treatment } & 0.039 & 0.028 & 0.044 & 0.063 \\
\hline \multicolumn{2}{|c|}{ CA $\mathrm{x}$ treatment } & 0.048 & 0.045 & 0.057 & 0.037 \\
\hline & atment & 0.007 & 0.002 & 0.003 & 0.004 \\
\hline
\end{tabular}

The invertebrates contain $0.5-2.0 \%$ of fat, but they constitute an important source of fatty acids. The energetic value of $100 \mathrm{~g}$ of invertebrates meat reaches ca. $100 \mathrm{kcal}$, but e.g. oysters provide only $59 \mathrm{kcal}$. The content of lipids in the analyzed frozen products of the Mediterranean diet (shrimp, squid, clams and octopus) ranged from $0.4 \mathrm{~g}$

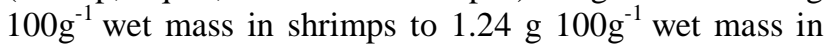
squids. A significantly higher fat content was determined 
in frozen squids (Table 1). A similar fat content in raw male squids was shown in a study by De Moreno et al. [15], whereas in female squids this value was lower. Fat

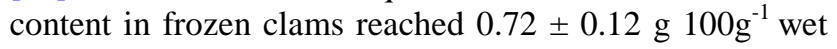
mass and was similar to the value obtained by Orban et al. [16] in raw clams caught in September. Fat content in individuals caught in June, December, February and July was significantly higher than in individuals caught in other months [16]. These authors confirm also that lipid content in the invertebrates, likewise that of protein, is strongly determined by the season of catch. According to Ozogul et al. [14] a significantly higher fat content is determined in individuals caught in autumn. This is linked with better availability of nutrients in the summer and autumn season $[17,18]$. According to many reports also size or age, reproductive status, geographic location, and sex influence fat content and composition of fish muscle $[2,3,19]$.

Lipids of aquatic invertebrates differ significantly in their fatty acid composition from these of land animals. According to Møller et al. [20], contents of saturated fatty acids (SFA), monoenoic fatty acids (MUFA) and polyenoic fatty acids (PUFA or PEFA) reaches 24-38\%, $21-42 \%$ and 26-45\%, respectively. Our study demonstrated that SFA content in frozen invertebrates (shrimp, squid, clams, octopus) was at a similar level and ranged from $33.90 \%$ in octopuses to $39.20 \% \mathrm{~g} / 100 \mathrm{~g}$ identified FA in clams (Table 2). The main SFAs in the analyzed seafoods were: myristic (C 14:0), palmitic (C16:0) and stearic (C18:0) acid (Table 2). Muscles of the analyzed clams was characterized by over two fold higher content of C14:0 acid compared to the other invertebrates, whereas content of C18:0 acid was by ca. 30\% higher ( $\mathrm{p} \leq$ 0.05 ) in tissues of shrimps. Results obtained in our study for fatty acid profile agreed with results reported by Orban et al. [16] for raw clams caught in September. The fatty acid composition in raw shrimps were similar to these determined by Bragagnolo and Rodriguez-Amaya [21] in raw small individuals of Xiphopenaeus kroyeri from the area of Säo Paulo. In other species of raw shrimps ( $P$. brasiliensis) originating from the region of Santa Catarina and having greater sizes, the content of SFA was lower and that of PUFA was higher. The presence of saturated fatty acids in diet, especially of myristic (14:0), palmitic (16:0) or lauric (12:0) acids and to a lesser extent of stearic acid (18:0), is not favorable from the health perspective as they are factors which contribute to increased concentration of cholesterol in low-density lipoproteins (LDL cholesterol). Saturated fatty acids may also facilitate the development of some neoplasms in humans and other mammals. Therefore, the recommended daily intake SFA in man is that below $10 \%$ of energy intake [22].

Table 2. Content of fatty acid in frozen of some products of the Mediterranean diet

\begin{tabular}{|c|c|c|c|c|c|c|c|c|}
\hline \multirow{2}{*}{ Fatty acid } & \multicolumn{4}{|c|}{ g/100 g identified FA } & \multicolumn{4}{|c|}{$\mathrm{g} / 100 \mathrm{~g}$ meat } \\
\hline & Shrimp & Squid & Clams & Octopus & Shrimp & Squid & Clams & Octopus \\
\hline C 14:0 & $3.04^{b} \pm 0.12$ & $2.94^{\mathrm{b}} \pm 0.05$ & $6.38^{\mathrm{a}} \pm 0.38$ & $2.86^{\mathrm{b}} \pm 0.11$ & $0.009^{b}$ & $0.029^{\mathrm{a}}$ & $0.034^{\mathrm{a}}$ & $0.021^{\mathrm{ab}}$ \\
\hline C $16: 0$ & $20.36^{b} \pm 2.11$ & $24.00^{a} \pm 2.47$ & $22.84^{\mathrm{ab}} \pm 3.09$ & $21.49^{\mathrm{ab}} \pm 2.48$ & $0.061^{\mathrm{C}}$ & $0.240^{\mathrm{A}}$ & $0.123^{\mathrm{B}}$ & $0.159^{\mathrm{B}}$ \\
\hline C $16: 1 \mathrm{n}-7$ & $3.61^{\mathrm{b}} \pm 0.69$ & $4.15^{\mathrm{b}} \pm 0.83$ & $9.69^{\mathrm{a}} \pm 0.69$ & $0.76^{\mathrm{C}} \pm 0.04$ & $0.011^{\mathrm{B}}$ & $0.041^{\mathrm{A}}$ & $0.052^{\mathrm{A}}$ & $0.006^{\mathrm{B}}$ \\
\hline C 18:0 & $12.88^{\mathrm{a}} \pm 1.02$ & $10.36^{\mathrm{b}} \pm 1.09$ & $9.98^{\mathrm{b}} \pm 0.65$ & $9.55^{b} \pm 0.78$ & $0.039^{\mathrm{b}}$ & $0.104^{\mathrm{a}}$ & $0.054^{\mathrm{b}}$ & $0.071^{\mathrm{ab}}$ \\
\hline C $18: 1 n-9$ & $12.95^{\mathrm{a}} \pm 1.18$ & $11.38^{\mathrm{a}} \pm 1.02$ & $8.38^{\mathrm{b}} \pm 0.67$ & $5.32^{\mathrm{C}} \pm 0.58$ & $0.039^{\mathrm{b}}$ & $0.114^{\mathrm{a}}$ & $0.045^{\mathrm{b}}$ & $0.039^{\mathrm{b}}$ \\
\hline C $18: 1 n-7$ & $6.05^{\mathrm{a}} \pm 0.22$ & $2.48^{\mathrm{c}} \pm 0.12$ & $4.51^{b} \pm 0.27$ & $2.93^{\mathrm{C}} \pm 0.22$ & 0.018 & 0.025 & 0.024 & 0.022 \\
\hline C $18: 2 n-6$ & $7.12^{\mathrm{A}} \pm 0.28$ & $1.30^{\mathrm{C}} \pm 0.03$ & $2.56^{\mathrm{BC}} \pm 0.09$ & $4.00^{B} \pm 0.08$ & $0.021^{\mathrm{b}}$ & $0.013^{\mathrm{c}}$ & $0.014^{\mathrm{c}}$ & $0.030^{\mathrm{a}}$ \\
\hline C $18: 3 n-3$ & $0.37 \pm 0.09$ & $0.60 \pm 0.01$ & $0.49 \pm 0.04$ & $0.56 \pm 0.05$ & 0.001 & 0.006 & 0.003 & 0.004 \\
\hline C $20: 1 n-9$ & $0.74^{\mathrm{C}} \pm 0.11$ & $1.25^{\mathrm{B}} \pm 0.12$ & $1.20^{\mathrm{B}} \pm 0.21$ & $2.75^{\mathrm{A}} \pm 0.02$ & $0.002^{\mathrm{c}}$ & $0.012^{\mathrm{b}}$ & $0.006^{\mathrm{c}}$ & $0.020^{\mathrm{a}}$ \\
\hline C $20: 3 n-6$ & $0.54^{C} \pm 0.02$ & $4.14^{\mathrm{A}} \pm 0.02$ & $1.24^{\mathrm{B}} \pm 0.01$ & $1.18^{\mathrm{B}} \pm 0.04$ & $0.002^{\mathrm{C}}$ & $0.041^{\mathrm{A}}$ & $0.007^{\mathrm{B}}$ & $0.009^{\mathrm{B}}$ \\
\hline C $20: 4 n-6$ & $8.56^{\mathrm{a}} \pm 1.03$ & $5.45^{b} \pm 0.71$ & $4.38^{\mathrm{b}} \pm 0.55$ & $4.14^{\mathrm{b}} \pm 0.17$ & $0.026^{\mathrm{c}}$ & $0.055^{\mathrm{a}}$ & $0.024^{\mathrm{c}}$ & $0.031^{\mathrm{b}}$ \\
\hline C $20: 5 n-3$ & $10.80^{\mathrm{b}} \pm 1.02$ & $13.09^{a} \pm 1.16$ & $14.81^{\mathrm{a}} \pm 1.04$ & $13.99^{a} \pm 0.53$ & $0.032^{\mathrm{C}}$ & $0.131^{\mathrm{A}}$ & $0.080^{\mathrm{B}}$ & $0.104^{\mathrm{AB}}$ \\
\hline C $22: 5 n-3$ & $0.75^{\mathrm{b}} \pm 0.08$ & $3.57^{\mathrm{a}} \pm 0.07$ & $1.08^{\mathrm{b}} \pm 0.03$ & $0.90^{\mathrm{b}} \pm 0.12$ & $0.002^{\mathrm{C}}$ & $0.036^{\mathrm{A}}$ & $0.006^{\mathrm{B}}$ & $0.007^{\mathrm{B}}$ \\
\hline C $22: 6 n-3$ & $12.22^{\mathrm{B}} \pm 0.65$ & $15.29^{B} \pm 0.53$ & $12.46^{\mathrm{B}} \pm 0.43$ & $29.57^{\mathrm{A}} \pm 0.22$ & $0.037^{\mathrm{d}}$ & $0.153^{b}$ & $0.067^{\mathrm{c}}$ & $0.219^{\mathrm{a}}$ \\
\hline Total FA & 100.00 & 100.00 & 100.00 & 100.00 & $0.300^{\mathrm{d}}$ & $1.000^{\mathrm{a}}$ & $0.540^{c}$ & $0.740^{\mathrm{b}}$ \\
\hline SFA & $36.28^{\mathrm{ab}} \pm 2.43$ & $37.31^{\mathrm{ab}} \pm 2.64$ & $39.20^{\mathrm{a}} \pm 2.85$ & $33.90^{b} \pm 3.04$ & $0.11^{\mathrm{c}}$ & $0.37^{\mathrm{a}}$ & $0.21^{\mathrm{b}}$ & $0.25^{b}$ \\
\hline MUFA & $23.35^{\mathrm{a}} \pm 2.19$ & $19.25^{\mathrm{a}} \pm 2.01$ & $23.79^{a} \pm 1.34$ & $11.76^{\mathrm{b}} \pm 0.99$ & $0.07^{\mathrm{b}}$ & $0.19^{\mathrm{a}}$ & $0.13^{\mathrm{ab}}$ & $0.09^{\mathrm{b}}$ \\
\hline PUFA & $40.36^{\mathrm{bc}} \pm 1.36$ & $43.44^{b} \pm 1.54$ & $37.01^{c} \pm 1.48$ & $54.34^{\mathrm{a}} \pm 1.42$ & $0.12^{\mathrm{C}}$ & $0.43^{\mathrm{a}}$ & $0.20^{\mathrm{b}}$ & $0.40^{\mathrm{b}}$ \\
\hline PUFA n-3 & $24.14^{\mathrm{c}} \pm 1.01$ & $32.55^{\mathrm{b}} \pm 1.26$ & $28.83^{b c} \pm 0.93$ & $45.02^{\mathrm{a}} \pm 0.77$ & $0.07^{\mathrm{c}}$ & $0.33^{\mathrm{a}}$ & $0.16^{\mathrm{b}}$ & $0.33^{\mathrm{a}}$ \\
\hline PUFA n-6 & $16.22^{\mathrm{a}} \pm 1.04$ & $10.89^{\mathrm{b}} \pm 0.67$ & $8.18^{\mathrm{c}} \pm 0.52$ & $9.32^{\mathrm{bc}} \pm 0.27$ & $0.05^{\mathrm{b}}$ & $0.11^{\mathrm{a}}$ & $0.04^{\mathrm{b}}$ & $0.07^{\mathrm{ab}}$ \\
\hline
\end{tabular}

$\mathrm{a}, \mathrm{b}, \mathrm{c}, \mathrm{d}-$ values in the same rows with different letters differ significantly $(\mathrm{p} \leq 0.05)$

A, B, C - values in the same rows with different letters differ significantly $(\mathrm{p} \leq 0.01)$

Among the MUFAs, the content of which was by ca. $50 \%$ lower in octopuses ( $\mathrm{p} \leq 0.05$ ) than in shrimps, clams and squids (Table 2), worthy of attention is the content of C18:1 acid ( $n-9$ and $n-7)$, the highest value (g/100 g FA) of which was determined in fat of shrimps as well as squids (C18:1 n-9) (Table 2). The clams were characterized by a significantly higher content of C16:1 n7 acid, and octopuses by a significantly higher content of C20:1 n-9 acid. In contrast, the content of PUFAs was the highest ( $\mathrm{p} \leq 0.05$ ) in octopuses, and the lowest in clams (Table 2). Frozen octopuses were characterized by a significantly higher (ca. 2-fold) content of docosahexaenoic acid (C22:6, DHA), which was reflected in a significantly higher content of n-3 family fatty acids (Table 2). Acc. to Navarro and Villanueva [23] squids were richer in $n-3$ PUFA than octopuses, whereas

octopuses had higher $n-6$ PUFA due to relatively high levels of 20:4 n-6. Squid paralarvae were particularly low in $n-6$ PUFA and thus showed a very high $n-3 / n-6$ ratio. DHA and EPA were also more abundant in squid and cuttlefish hatchlings as compared to octopus paralarvae [23].

Among the analyzed PUFAs (n-3), worthy of attention are also: EPA (C20:5; n-3), the content of which was significantly lower in shrimps $(\mathrm{p} \leq 0.05)$, and C22:5 acid (n-3) a significantly higher content of which was determined in squids. In turn, shrimps were characterized by a significantly higher contributions of n- 6 fatty acids, C18:2 ( $\leq 0.01)$ and 20:4 acid $(\mathrm{p} \leq 0.05)$ in particular (Table 2). In their case, the $n-3 / n-6$ ratio reached 1.49 and was significantly lower compared to the other analyzed seafoods (Table 3). 
Table 3. Content of fatty acid in fried of some products of the Mediterranean diet

\begin{tabular}{|c|c|c|c|c|c|c|c|c|}
\hline \multirow{2}{*}{ Fatty acid } & \multicolumn{4}{|c|}{ g/100 g identified FA } & \multicolumn{4}{|c|}{$\mathrm{g} / 100 \mathrm{~g}$ meat } \\
\hline & Shrimp & Squid & Clams & Octopus & Shrimp & Squid & Clams & Octopus \\
\hline C 14:0 & $0.15^{\mathrm{b}} \pm 0.02$ & $0.16^{\mathrm{b}} \pm 0.01$ & $0.19^{\mathrm{b}} \pm 0.04$ & $0.29^{\mathrm{a}} \pm 0.09$ & 0.05 & 0.06 & 0.05 & 0.09 \\
\hline C $16: 0$ & $7.88 \pm 0.98$ & $7.96 \pm 1.01$ & $7.63 \pm 0.99$ & $8.13 \pm 1.08$ & $2.67^{\mathrm{ab}}$ & $3.08^{\mathrm{a}}$ & $2.10^{\mathrm{b}}$ & $2.43^{\mathrm{ab}}$ \\
\hline C $16: 1 n-7$ & $0.11 \pm 0.04$ & $0.12 \pm 0.01$ & $0.13 \pm 0.03$ & $0.09 \pm 0.02$ & 0.04 & 0.05 & 0.04 & 0.03 \\
\hline C 18:0 & $3.19^{c} \pm 0.12$ & $4.10^{b} \pm 0.29$ & $4.35^{\mathrm{ab}} \pm 0.29$ & $4.81^{\mathrm{a}} \pm 0.26$ & $1.08^{\mathrm{b}}$ & $1.59^{\mathrm{a}}$ & $1.20^{\mathrm{ab}}$ & $1.44^{\mathrm{ab}}$ \\
\hline C $18: 1 n-9$ & $19.37 \pm 1.98$ & $21.10 \pm 2.14$ & $20.82 \pm 1.82$ & $21.43 \pm 1.73$ & $6.55^{\mathrm{b}}$ & $8.16^{\mathrm{a}}$ & $5.73^{\mathrm{b}}$ & $6.39^{\mathrm{b}}$ \\
\hline C $18: 1 n-7$ & $0.34^{\mathrm{b}} \pm 0.02$ & $0.49^{\mathrm{ab}} \pm 0.08$ & $0.72^{\mathrm{a}} \pm 0.11$ & $0.68^{\mathrm{a}} \pm 0.12$ & $0.12^{\mathrm{b}}$ & $0.19^{\mathrm{a}}$ & $0.20^{\mathrm{a}}$ & 0.20 \\
\hline C $18: 2 n-6$ & $59.73 \pm 5.12$ & $56.81 \pm 5.03$ & $58.56 \pm 5.19$ & $56.05 \pm 5.05$ & $20.21^{\mathrm{a}}$ & $21.97^{\mathrm{a}}$ & $16.13^{\mathrm{b}}$ & $16.72^{\mathrm{b}}$ \\
\hline C $18: 3 n-3$ & $0.37^{\mathrm{B}} \pm 0.01$ & $0.27^{\mathrm{B}} \pm 0.01$ & $0.93^{\mathrm{A}} \pm 0.02$ & $0.88^{\mathrm{A}} \pm 0.22$ & $0.13^{\mathrm{b}}$ & $0.10^{\mathrm{b}}$ & $0.26^{\mathrm{a}}$ & $0.26^{\mathrm{a}}$ \\
\hline C $20: 1 n-9$ & $0.19^{\mathrm{B}} \pm 0.01$ & $0.28^{\mathrm{B}} \pm 0.02$ & $0.18^{\mathrm{B}} \pm 0.01$ & $0.52^{\mathrm{A}} \pm 0.07$ & $0.06^{\mathrm{b}}$ & $0.11^{\mathrm{ab}}$ & $0.05^{\mathrm{b}}$ & $0.16^{\mathrm{a}}$ \\
\hline C $20: 3 n-6$ & $0.13^{\mathrm{B}} \pm 0.02$ & $0.49^{\mathrm{A}} \pm 0.04$ & $0.07^{\mathrm{B}} \pm 0.01$ & $0.11^{\mathrm{B}} \pm 0.02$ & $0.04^{\mathrm{B}}$ & $0.19^{\mathrm{A}}$ & $0.02^{\mathrm{B}}$ & $0.03^{\mathrm{B}}$ \\
\hline C $20: 4 n-6$ & $5.68^{\mathrm{a}} \pm 0.56$ & $5.12^{a} \pm 0.48$ & $3.14^{\mathrm{b}} \pm 0.28$ & $3.91^{\mathrm{b}} \pm 0.33$ & $1.92^{\mathrm{a}}$ & $1.98^{\mathrm{a}}$ & $0.86^{\mathrm{b}}$ & $1.17^{\mathrm{b}}$ \\
\hline C $20: 5 n-3$ & $1.14^{\mathrm{a}} \pm 0.11$ & $0.93^{\mathrm{ab}} \pm 0.07$ & $0.82^{\mathrm{ab}} \pm 0.06$ & $0.52^{\mathrm{b}} \pm 0.02$ & $0.39^{\mathrm{a}}$ & $0.36^{\mathrm{a}}$ & $0.23^{\mathrm{b}}$ & $0.16^{\mathrm{c}}$ \\
\hline C $22: 5 n-3$ & $0.12^{\mathrm{C}} \pm 0.01$ & $0.46^{\mathrm{a}} \pm 0.03$ & $0.31^{\mathrm{b}} \pm 0.03$ & $0.11^{\mathrm{c}} \pm 0.02$ & $0.04^{\mathrm{c}}$ & $0.18^{\mathrm{a}}$ & $0.09^{\mathrm{b}}$ & $0.03^{c}$ \\
\hline C $22: 6 n-3$ & $1.59^{b} \pm 0.21$ & $1.68^{\mathrm{b}} \pm 0.14$ & $2.14^{\mathrm{a}} \pm 0.17$ & $2.45^{\mathrm{a}} \pm 0.27$ & 0.54 & 0.65 & 0.59 & 0.73 \\
\hline Total FA & 100.00 & 100.00 & 100.00 & 100.00 & $33.83^{b}$ & $38.68^{\mathrm{a}}$ & $27.54^{\mathrm{C}}$ & $29.84^{\mathrm{bc}}$ \\
\hline SFA & $11.22^{b} \pm 0.91$ & $12.23^{\mathrm{ab}} \pm 0.97$ & $12.17^{\mathrm{ab}} \pm 0.87$ & $13.23^{\mathrm{a}} \pm 0.94$ & $3.80^{\mathrm{ab}}$ & $4.73^{\mathrm{a}}$ & $3.35^{\mathrm{b}}$ & $3.95^{\mathrm{ab}}$ \\
\hline MUFA & $20.01 \pm 1.71$ & $21.99 \pm 1.91$ & $21.85 \pm 1.84$ & $22.73 \pm 1.76$ & $6.77^{\mathrm{ab}}$ & $8.51^{\mathrm{a}}$ & $6.02^{\mathrm{b}}$ & $6.78^{\mathrm{ab}}$ \\
\hline PUFA & $68.77 \pm 4.81$ & $65.78 \pm 5.11$ & $65.98 \pm 4.65$ & $64.04 \pm 5.11$ & $23.26^{\mathrm{a}}$ & $25.44^{\mathrm{a}}$ & $18.17^{\mathrm{b}}$ & $19.11^{\mathrm{b}}$ \\
\hline PUFA n-3 & $3.23 \pm 0.22$ & $3.35 \pm 0.18$ & $4.21 \pm 0.12$ & $3.97 \pm 0.21$ & 1.09 & 1.30 & 1.16 & 1.18 \\
\hline PUFA n-6 & $65.54 \pm 4.98$ & $62.43 \pm 5.01$ & $61.77 \pm 4.94$ & $60.07 \pm 4.83$ & $22.17^{\mathrm{a}}$ & $24.15^{\mathrm{a}}$ & $17.01^{\mathrm{b}}$ & $17.92^{\mathrm{b}}$ \\
\hline
\end{tabular}

a. b. c - values in the same rows with different letters differ significantly $(\mathrm{p} \leq 0.05)$

A, B - values in the same rows with different letters differ significantly $(\mathrm{p} \leq 0.01)$

As described by Bragagnolo and Rodriguez-Amaya [21], the content of n-3 fatty acids depends on the species of marine organisms and many environmental factors. They determined a significantly higher content of these acids in wild shrimps, especially these of larger sizes, a lower content in fresh-water fish and the lowest in cultured shrimps. This indicates that the marine environment provides an excellent source of $n-3$ rich foods [24]. Ackman and Takeuchi [25] have reported that the percentage of n-3 PUFA in cultured marine fish lipids is often lower than that in their wild counterparts because the manufactured feeds usually contain high proportions of lipids rich in SFA and MUFA, but are deficient in n-3 PUFA.

Lipids of marine animals are rich sources of the $n-3$ family fatty acids and, thus, exhibit anti-atherogenic and anti-thrombogenic properties [26,27]. In fat of the analyzed invertebrates, the atherogenic (AI) and thrombogenic (TI) indices were lower compared to most fats of plant origin, which was due to a very high content of n-3 polyunsaturated fatty acids. The presented lipid indices (Table 4) demonstrate that the consumption of these products reduces the risk of ischemic heart disease and arterial hypertension, and prevents some disorders of heart rhythm [28]. Clams had the least favorable indicator $\mathrm{h} / \mathrm{H}$ (1.71) while shrimp and octopus had the most favorable (2.54-2.57). The reasons for the significantly higher share of myristic acid in the fat of clams (Table 2).

Table 4. Fatty acids ratio and artherogenic (AI) and thrombogenicity index (TI) and hypocholesterolemic/Hypercholesterolemic (h/H) ratio in some products of the Mediterranean diet

\begin{tabular}{|c|c|c|c|c|c|}
\hline & & Shrimp & Squid & Clams & Octopus \\
\hline \multirow[t]{2}{*}{ n-6/n-3 ratio } & Freezing & $0.67^{\mathrm{a}} \pm 0.09$ & $0.33^{\mathrm{b}} \pm 0.04$ & $0.28^{\mathrm{bc}} \pm 0.03$ & $0.21^{\mathrm{c}} \pm 0.03$ \\
\hline & Frying & $20.30^{\mathrm{a}} \pm 0.78$ & $18.64^{\mathrm{ab}} \pm 0.69$ & $14.64^{\mathrm{b}} \pm 0.62$ & $15.13^{b} \pm 0.54$ \\
\hline \multirow[t]{2}{*}{ n-3/n-6 ratio } & Freezing & $1.49^{\mathrm{C}} \pm 0.11$ & $2.99^{b} \pm 0.21$ & $3.53^{\mathrm{ab}} \pm 0.24$ & $4.83^{\mathrm{a}} \pm 0.29$ \\
\hline & Frying & $0.05 \pm 0.01$ & $0.05 \pm 0.01$ & $0.07 \pm 0.02$ & $0.07 \pm 0.01$ \\
\hline \multirow[t]{2}{*}{ AI } & Freezing & $0.51^{b} \pm 0.09$ & $0.57^{\mathrm{b}} \pm 0.11$ & $0.80^{\mathrm{a}} \pm 0.12$ & $0.50^{\mathrm{b}} \pm 0.09$ \\
\hline & Frying & $0.10 \pm 0.02$ & $0.10 \pm 0.03$ & $0.10 \pm 0.02$ & $0.11 \pm 0.02$ \\
\hline \multirow[t]{2}{*}{$\mathrm{TI}$} & Freezing & $0.39^{\mathrm{a}} \pm 0.08$ & $0.32^{\mathrm{a}} \pm 0.07$ & $0.33^{\mathrm{a}} \pm 0.06$ & $0.20^{\mathrm{b}} \pm 0.05$ \\
\hline & Frying & $0.21 \pm 0.03$ & $0.23 \pm 0.02$ & $0.21 \pm 0.03$ & $0.24 \pm 0.04$ \\
\hline \multirow[t]{2}{*}{$\mathrm{h} / \mathrm{H}$} & Freezing & $2.54^{\mathrm{a}} \pm 0.19$ & $2.13^{\mathrm{ab}} \pm 0.22$ & $1.71^{\mathrm{b}} \pm 0.18$ & $2.57^{\mathrm{a}} \pm 0.21$ \\
\hline & Frying & $11.02 \pm 0.43$ & $10.76 \pm 0.51$ & $11.19 \pm 0.49$ & $10.23 \pm 0.37$ \\
\hline AI x treatment & & 0.016 & 0.015 & 0.011 & 0.018 \\
\hline TI $\mathrm{x}$ treatment & & 0.023 & 0.048 & 0.025 & 0.128 \\
\hline $\mathrm{h} / \mathrm{H}$ x treatment & & 0.011 & 0.009 & 0.007 & 0.013 \\
\hline
\end{tabular}

er significantly $(\mathrm{p} \leq 0.0$

\subsection{Effect of Processing Treatments on Contents of Basic Nutrients and Fatty Acids of Seafoods}

During storage of frozen seafoods, many changes are likely to occur in the structure of nutrients, which has a significant impact on, e.g., texture of the finished product. It may also slightly affect the content of nutrients [29,30,31].

Dry matter content in the analyzed fried products of the Mediterranean diet increased over five fold in shrimps and squids and over four fold and almost three fold in clams and octopuses, respectively (Table 1). It corresponded with a significant increase in the content of nutrients, i.e. both protein and fat. It was caused mainly by water loss, addition of coating (flour) and presence of oil used for frying. In addition, frying results in irreversible chemical and physical changes. Each oil in the liquid form is subject to oxidation, which results in changes of its chemical structure and viscosity. The nutritive value of fried products changes as well. During frying, meat goes limp, loses high volume of water, and absorbs fat. The more drier the meat is and the longer the frying time period), the more fat is absorbs [31]. This dependency was also observed in our study, as squids were characterized by a significantly lower water content, which was 
consistent with a significantly higher content of fat, compared to the other analyzed invertebrates (Table 1). Similar correlations were determined by Garcia-Arias et al. [32]. Worthy of mention is also that inappropriate frying leads to chemical transformations that result in the formation of toxic complexes of atomic and sub-atomic bonds which decrease and modify protein value.

The conducted analyses demonstrate that frying caused also changes in the fatty acids composition of the analyzed seafoods (Table 3), i.e. over 30\% decrease of total SFAs and a significant increase in PUFAs content in all analyzed invertebrates subjected to frying process. The lowered total content of SFAs was due to reduced contents of C14:0, C16:0 and C18:0, whereas the increase in PUFAs was caused only by increased content of C18:2 n6 acid and to a lesser extent of C18:3 n-3 acid. This resulted from the use of sunflower oil for frying, which is a rich source of these acids (Table 5). Similar observations were made by Sanchez-Muniz et al. [33] according to whom the change of fatty acid composition in food products during frying was due to gradients of fatty acids. Frying on olive oil with a low content of linoleic acid considerably increases contents of oleic and linoleic acids, which in turns reduces concentrations of most of the other fatty acids. Similar dependencies were noted in our study, as the content of the remaining fatty acids of the PUFA family decreased significantly. Special attention should be paid to a significant reduction in contents of $n-3$ family fatty acids, which caused an unbeneficial change in n-6/n3 ratio and lipid indices. According to many authors, in fat fish the exchange of fat between fried products and oil used for frying leads to increasing losses of some valuable fatty acids like eicosapentaenoic and docosahexaenoic acids [33,34]. Also Morami et al. [6] demonstrate that depending on the applied heat treatment (roasting, frying, microwaving), the fatty acid composition (especially contents of EPA and DHA) changes significantly. It is especially important in products after frying owing to high sorption of frying fat by coating. Such changes observed also in margarines as well as refined and partly hydrogenated oils had adverse effects on the synthesis of prostaglandins and thromboxanes, which leads to arterial hypertension, contraction of blood vessels and some immune disorders. This may lead to the development of selected inflammatory diseases and various allergies. Frying in sunflower oil contributed a significant reduction in $\mathrm{AI}$ and $\mathrm{TI}$ indicators and improve the ratio of $\mathrm{h} / \mathrm{H}$, for all four species displaying a range of indices in frozen form (Table 4).

Table 5. Content of dry matter (DM), crude protein (CP), crude ash (CA) and crude fat (CF) (\% wet mass) and fatty acids in sunflower oil and wheat flour $(\mathrm{n}=3)$

\begin{tabular}{|c|c|c|c|c|}
\hline Item & \multicolumn{2}{|c|}{ Sunflower oil (before frying) } & \multicolumn{2}{|c|}{ Wheat flour } \\
\hline $\mathrm{DM}$ & \multicolumn{2}{|c|}{$99.98 \pm 0.16$} & \multicolumn{2}{|c|}{$87.11 \pm 0.39$} \\
\hline $\mathrm{CP}$ & \multicolumn{2}{|c|}{0.00} & \multicolumn{2}{|c|}{$12.31 \pm 0.24$} \\
\hline CA & \multicolumn{2}{|c|}{$0.01 \pm 0.001$} & \multicolumn{2}{|c|}{$0.57 \pm 0.04$} \\
\hline Fatty acids & g/100 g identified FA & g/100 g product & g/100 g identified FA & g/100 g product \\
\hline C 14:0 & $0.12 \pm 0.02$ & $0.10 \pm 0.02$ & $0.15 \pm 0.03$ & $0.002 \pm 0.001$ \\
\hline C 16:0 & $5.84 \pm 0.24$ & $4.97 \pm 0.21$ & $19.21 \pm 0.19$ & $0.194 \pm 0.012$ \\
\hline C $16: 1 n-7$ & $0.15 \pm 0.02$ & $0.13 \pm 0.03$ & $0.51 \pm 0.05$ & $0.005 \pm 0.001$ \\
\hline C 18:0 & $3.92 \pm 0.19$ & $3.34 \pm 0.16$ & $0.96 \pm 0.09$ & $0.010 \pm 0.001$ \\
\hline C $18: 1 n-9$ & $16.59 \pm 0.44$ & $14.10 \pm 0.39$ & $17.58 \pm 0.48$ & $0.178 \pm 0.019$ \\
\hline C $18: 1 n-7$ & $1.53 \pm 0.11$ & $1.31 \pm 0.12$ & $1.06 \pm 0.09$ & $0.011 \pm 0.002$ \\
\hline C $18: 2 n-6$ & $70.38 \pm 1.24$ & $59.82 \pm 1.67$ & $56.23 \pm 1.31$ & $0.568 \pm 0.065$ \\
\hline C $18: 3 n-3$ & $0.63 \pm 0.07$ & $0.54 \pm 0.05$ & $3.65 \pm 0.17$ & $0.037 \pm 0.003$ \\
\hline C $20: 1 n-9$ & $0.18 \pm 0.02$ & $0.16 \pm 0.03$ & $0.12 \pm 0.02$ & $0.001 \pm 0.001$ \\
\hline C $20: 3 n-6$ & $0.11 \pm 0.02$ & $0.10 \pm 0.02$ & $0.23 \pm 0.03$ & $0.002 \pm 0.001$ \\
\hline C $22: 1 n-9$ & $0.29 \pm 0.03$ & $0.25 \pm 0.03$ & $0.09 \pm 0.01$ & $0.001 \pm 0.001$ \\
\hline C 24:0 & $0.09 \pm 0.01$ & $0.08 \pm 0.01$ & $0.11 \pm 0.01$ & $0.001 \pm 0.001$ \\
\hline C $24: 1 n-9$ & $0.14 \pm 0.01$ & $0.12 \pm 0.02$ & $0.09 \pm 0.01$ & $0.001 \pm 0.001$ \\
\hline Total FA & 100.00 & $85.00 \pm 1.84$ & 100.00 & $1.010 \pm 0.112$ \\
\hline SFA & $9.98 \pm 0.32$ & $8.48 \pm 0.29$ & $20.43 \pm 0.62$ & $0.207 \pm 0.017$ \\
\hline MUFA & $18.90 \pm 0.49$ & $16.06 \pm 0.38$ & $19.45 \pm 0.46$ & $0.196 \pm 0.013$ \\
\hline PUFA & $71.12 \pm 1.21$ & $60.45 \pm 1.36$ & $60.12 \pm 1.27$ & $0.607 \pm 0.028$ \\
\hline PUFA n-3 & $0.63 \pm 0.14$ & $0.54 \pm 0.12$ & $3.65 \pm 0.29$ & $0.04 \pm 0.001$ \\
\hline PUFA n-6 & $70.49 \pm 1.19$ & $59.92 \pm 1.08$ & $56.46 \pm 1.02$ & $0.57 \pm 0.032$ \\
\hline$n-6 / n-3$ ratio & \multicolumn{2}{|c|}{$111.85 \pm 2.45$} & \multirow{2}{*}{\multicolumn{2}{|c|}{$\begin{array}{c}15.46 \pm 0.26 \\
0.06 \pm 0.01\end{array}$}} \\
\hline n-3/n-6 ratio & 0.0 & & & \\
\hline
\end{tabular}

\section{Conclusion}

Frozen seafoods, octopuses and squid in particular, are rich sources of high-quality protein and small, though valuable, sources of fat, especially PUFAs and PUFAs of the n-3 family. Frying with oil reduces differences in the proportion of fatty acid n-3/n-6 family and values of atherogenic (AI) and thrombogenic indices (TI) and h/H between the analyzed of seafood meat.

Frying in sunflower oil caused a significant decrease in contents of SFAs and n-3 fatty acids and a significant increase in contents of PUFA and n-6 fatty acids, resulting in a significant increase in $n-6 / n-3$ ratio, which was associated with the use of sunflower oil for frying. Consequently there was a significant decrease in values of $\mathrm{AI}$ and $\mathrm{TI}$, with a significant increase in $\mathrm{h} / \mathrm{H}$ ratio, which is beneficial from the nutritional point of view.

\section{Acknowledgements}

The authors thank the native speaker Mrs Jennifer Nielsen-Kahn from Department of Plant Biology and Pathology, SEBS, Rutgers University, New Brunswick, USA, for language help. 


\section{References}

[1] Dong, F.M. "The nutritional value of shellfish in Washington Sea Grant, Seattle,” Washington, USA, 2001, 1-8.

[2] Rasoarahona, J.R.E., Barnathan, G., Pianchini, B.J. and Gaydon, E.M. "Influence of season on the lipid content and fatty acid profiles of three tilapia species Oreochromsis niloticus, $O$. macrochir and Tilapia rendalli from Madagascar," Food Chemistry, 91. 683-694. 2005.

[3] Musa, A.S.M. "Nutritional quality components of indigenous freshwater fish species, Puntius stigma in Bangladesh," Bangladesh Journal of Scientific and Industrial Research, 443. 367-370. 2009.

[4] Reames, E. "Nutritional benefits of seafood," Southern Regional Aquaculture Center. No. 7300, 2012, 1-6.

[5] Decker, E.A., Akoh, C.C. and Wilkes, R.S. „Incorporation of n-3 fatty acids in foods: challenges and opportunities," Journal of Nutrition, 142. 610S-613S. 2012.

[6] Morami, Y., Bakar, J., Syed Muhamad, S.H. and Che Man, Y. "Effects of different final cooking methods on physico-chemical properties of breaded fish fillets," American Journal of Food Technology, 44. 136-145. 2009.

[7] Czech A. and Stachyra, K. "Effect of processing treatments frozen, frying on contents of minerals in tissues of 'frutti di mare'," International Journal of Food Science and Technology, 482. 238245. 2013.

[8] AOAC "Official Methods of Analysis. International, 17th ed., AOAC Inter., Gaithersburg, MD, USA, 2000.

[9] Folch, J., Lees, M. and Stanley, G.H.S. "A simple method for the isolation and purification of total lipids from animal tissue," The Journal of Biological Chemistry, 226. 497-509. 1957.

[10] Weihrauch, J.L., Posati, L. P., Anderson, B.A. and Exler, J. "Lipid conversion factors for calculating fatty acids contents in foods," JAOCS, 54. 36-40, 1977.

[11] Ulbricht, T.L.V. and Southgate, D.A.T. "Coronary disease seven dietary factors,” Lancet, 338. 985-992. 1991.

[12] Fernández, M., Ordóñez, J.A., Cambero, I., Santos, C., Pin, C. and de la Hoz, L. "Fatty acid compositions of selected varieties of Spanish ham related to their nutritional implications," Food Chemistry, 101. 107-112. 2007.

[13] Korhonen, H., Pihlanto-Leppäla, A., Rantamäki, P. and Tupasela, T. "Impact of processing on bioactive proteins and peptides," Trends in Food Science and Technology, 9. 307-319. 1998.

[14] Ozogul, Y., Duysak, O., Ozogul, F., Özkütük, A.S. and Türeli, C. "Seasonal effects in the nutritional quality of the body structural tissue of cephalopods,” Food Chemistry, 108. 847-852. 2008.

[15] De Moreno, J.E.A., Moreno, V.J., Ricci, L., Roldan, M. and Gerpe, M. "Variations in the biochemical composition of the squid Illex argentinus from the South Atlantic Ocean," Comparative Biochemistry and Physiology Part B, 119. 631-637. 1998.

[16] Orban, E., Lena, G.D., Nevigato, T., Casini, I. Caproni, R., Santaroni, G. and Giulini, G. "Nutritional and commercial quality of the striped venus clam, Chamelea gallina, from the Adriatic sea," Food Chemistry, 101. 1063-1070. 2006.

[17] Robards, D.M., Anthony, J.A., Rose, G.A. and Piatt, J.F. "Changes in proximate composition and somatic energy content for Pacific sand lance Ammodytes hexapterus from Kachemak," Journal of Experimental Marine Biology and Ecology, 242. 245258. 1999.

[18] Rosa, R., Nunes, M.L. and Sousa Reis, C. "Seasonal changes in the biochemical composition of Octopus vulgaris, Cuvier, 1797, from three areas of the Portuguese coast," Bulletin of Marine Science, 71. 739-751. 2002.
[19] Saito, H., Yamashiro, R., Alasalvar, C. and Konno, T. "Influence of diet on fatty acids of three subtropical fish, subfamily caesioninae Caesio diagramma and C. tile and family siganidae Siganus canaliculatus, ” Lipids, 34. 1073-1082. 1999.

[20] Møller, A., Saxholt, E., Christensen, A.T., Hartkopp, H.B. and Hess Ygil, K. "Danish Food Composition Databank”, revision 6.0, Food Informatics, Department of Nutrition, Danish Institute for Food and Veterinary Research, June 2005. http://www.foodcomp.dk

[21] Bragagnolo, N. and Rodriguez-Amaya, D.B. "Total lipid, cholesterol, and fatty acids of farmed freshwater prawn Macrobrachium rosenbergii and wild marine shrimp Penaeus brasiliensis, Penaeus schimitti, Xiphopenaeus kroyeri,” Journal of Food Composition and Analysis, 14. 359-369. 2001.

[22] Bałasińska, B., Jank, M. and Kulasek, G. "The properties and the role of polyunsaturated fatty acids in maintaining the health of humans and animals," Życie Weterynaryjne, 859. 749-753. 2010. in Polish.

[23] Navarro, J.C. and Villanueva, R. "Lipid and fatty acid composition of early stages of cephalopods: an approach to their lipid requirements,” Aquaculture, 183. 161-177. 2000.

[24] Renon, P., Malandra, R., Biondi, P.A. and Ronchi, S. "Wild and aquacultured sea breams: studies on total lipids, cholesterol and fatty acids,” Inginiera Alimentaria Consumables. Animalia, 10. 21-28. 1994.

[25] Ackman, R.G. and Takeuchi, T. "Comparison of fatty acid and lipids of smelting hatchery-fed and wild Atlantic salmon Salmo salar,” Lipids, 21. 117-120. 1986.

[26] Henderson, S., Lampel, J. and Hollenbeck, C.B. "The effects of a 4:1 eicosapentaenoic acid/docosahexaenoic acid fish oil supplement on plasma lipid profile," Journal of the American Dietetic Association, 1089. 104-115. 2008.

[27] $\mathrm{Hu}, \mathrm{F} . \mathrm{B}$. "The balance between $\omega-6$ and $\omega-3$ fatty acids and the risk of coronary heart disease,” Nutrition, 179. 741-742. 2001.

[28] Kris-Etherton, P.M., Harris, W.S. and Appel, L.J. "Fish consumption, fish oil, omega-3 fatty acids, and cardiovascular disease," Circulation, 106. 2747-2757. 2002.

[29] Codex Alimentarius 2004 Codex Standard for Quick Frozen Fish Sticks Fish Fingers, Fish Portions and Fish Fillets-Breaded or in Batter Codex Stan 166-1989, Rev. 2

[30] Cunnane, S., Drevon, ChA., Harris, B., Sinclair, A. and Spector, A "Recommendations for intake of polyunsaturated fatty acids in healthy adults,” Report prepared for the International Society for the Study of Fatty Acids and Lipids, June 2004. Available at: «http://www.issfal.org.uk/PUFAIntakeReccomdFinalReport.pdf». Accessed Mar. 7, 2006.

[31] Musaiger, A.O. and D’Souza, R. “The effects of different methods of cooking on proximate, mineral and heavy metal composition of fish and shrimps consumed in the Arabian Gulf," Archivos Latinoamericanos de Nutricion, 58. 103-109. 2008.

[32] Garcia-Arias, M.T., Álvarez Pontes, E., García-Linaresa, M.C., García-Fernández, M.C. and Sánchez-Muniz, F.J. “Cookingfreezing-reheating CFR of sardine Sardina pilchardus fillets. Effect of different cooking and reheating procedures on the proximate and fatty acid compositions," Food Chemistry, 83. 349356. 2003.

[33] Sanchez-Muniz, F.J., Viejo, J.M. and Medina, R. "Deep frying of sardines in different culinary fats. Changes in the fatty acid composition of sardines and frying fats,” Journal of Agricultural and Food Chemistry, 40. 2252-2256. 1992.

[34] Varela, G. and Ruiz-Roso B. "Some effects of deep frying on the dietary fat intake,” Nutrition Reviews, 50. 256-262. 1992. 